\title{
Correction: Interior spaces as traces in Balzac's La Comédie humaine
}

\section{Dominique Bauer}

Correction to: Palgrave Communications (2017) 3, Article number: 17043 doi: 10.1057/palcomms.2017.43; Published 1 Jun 2017; Updated 11 May 2017

In the section entitled "A modern sense of historicity. The lost past and its recuperation" in the last paragraph the sentence, "In the same context, Mistral's Museon Arlaten sheltered the very last cabane of Salin-de-Giraud (Galtier, 1977: 17-18), thus preserving objects and buildings in situ, in their material, tangible place." has been corrected to "In the same context, Mistral's Museon Arlaten would later shelter the very last cabane of Salin-de-Giraud (Galtier, 1977: 17-18), thus preserving objects and buildings in situ, in their material, tangible place."

In the same section "Passagen(arbeit)" has been corrected to "Passagenwerk".

The article has been corrected online.

(c) (i)

This work is licensed under a Creative Commons Attribution 4.0 International License. The images or other third party material in this article are included in the article's Creative Commons license, unless indicated otherwise in the credit line; if the material is not included under the Creative Commons license, users will need to obtain permission from the license holder to reproduce the material. To view a copy of this license, visit http://creativecommons.org/licenses/by/4.0/

(C) The Author(s) 2018 